\title{
Analisis Desain Rencana Pelaksanaan Pembelajaran (RPP) pada Mata Pelajaran Sejarah di SMA Negeri 1 Sanggar
}

\author{
Rian Utama ${ }^{1),}$, Syahbuddin $^{1)}$, Much. Noeryoko ${ }^{1)}$ \\ ${ }^{1)}$ STKIP Taman Siswa Bima \\ *rianutama@gmail.com
}

Artikel Info

Tanggal Publikasi

2020-06-30

Kata Kunci

Desain RPP

Mata Pelajaran

Sejarah

Permendikbud

\section{Abstrak}

Peneitian ini bertujuan menganalisis desain rencana pelaksanaan pembelajaran (RPP) pada mata pelajaran sejarah di SMA Negeri 1 Sanggar berdasarkan Permendikbud No. 22 tahun 2016. Dua aspek penting yang dianalisis adalah kelengkapan dan sistematika penyusunan komponen RPP dan kesesuaian isi RPP berdasarkan Permendikbud No. 22 tahun 2016. Penelitian ini menggunakan pendekatan kualitatif dengan metode deskripstif. Pengumpulan data menggunakan teknik studi dokumentasi terhadap desain perencanaan pelaksanaan pembelajaran (RPP) mata pelajaran Sejarah di SMA Negeri 1 Sanggar. Validasi data dengan perpanjangan pengamatan dan meningkatkan ketekunan serta triangulasi teori. Analisis data merujuk peda pendapat Miles dan Huberman (1884), aktivitas dalam analisis data yaitu data reduction, data display, conclusion drawing/verification. Berdasarkan uraian-uraian di atas dapat disimpulkan sebagai berikut: (a) Desain rencana pelaksanaan pembelajaran (RPP) yang dikembangkan oleh guru mata pelajaran sejarah di SMA Negeri 1 Sanggar sesuai dengan ketentuan dari Permendikbud No. 22 Tahun 2016 sedangkan perbedaannya pada sistematika. (b) Isi Desain rencana pelaksanaan pembelajaran (RPP) yang dikembangkan oleh guru mata pelajaran sejarah di SMA Negeri 1 Sanggar sesuai dengan ketentuan Permendikbud No. 22 Tahun 2016.

\section{Pendahuluan}

Upaya pemerintah dalam meningkatkan mutu pendidikan salah satunya adalah pengembangan kurikulum. Pengembangan kurikulum di Indonesia telah belangsung sebanyak sebelas kali yaitu tahun 1947 yang disebut dengan "Rentjana Pelajaran 1947", yang baru dilaksanakan pada tahun 1950, Kurikulum 1952 (Rentjana Pelajaran Terurai 1952), Kurikulum 1964 (Rentjana Pendidikan 1964), Kurikulum 1968, Kurikulum 1975, Kurikulum 1984 (Kurikulum 1975 yang disempurnakan), Kurikulum 1994 dan Suplemen Kurikulum 1999, Kurikulum 2004, "KBK (Kurikulum Berbasis Kompetensi)", Kurikulum 2006, "KTSP (Kurikulum Tingkat Satuan Pendidikan), Kurikulum 2013 (Alhamuddin, 2015: 49-53).

Perubahan di atas merupakan refleksi dari perubahan sistem politik, sosial budaya, ekonomi, dan perkembangan ilmu pengetahuan dan teknologi (Iptek) dalam kehidupan masyarakat berbangsa dan bernegara. Kurikulum 2013 yang lahir paska reformasi merupakan refleksi dari perkembangan masyarakat dan Iptek. Pasca reformasi ternyata korupsi, kolusi dan nepotisme makin merajalela, disintegrasi bangsa.

Kurikulum 2013 yaitu kurikulum yang terintegrasi, maksudnya adalah suatu model kurikulum yang dapat mengintegrasikan skill, themes, concepts, and topics baik dalam bentuk within singel disciplines, across several disciplines and within and across learners (Poerwati, Sofan Amri, 2013: 28). Kurikulum 2013 mempunyai tujuan untuk mendorong peserta didik atau siswa, mampu lebih baik melakukan observasi, bertanya, bernalar, dan mengkomunikasikan (mempresentasikan) apa yang mereka peroleh atau mereka ketahui setelah menerima materi pelajaran (Mulyasa, 2013: 65). Hal ini seuai dengan amanat 
UU 20 Tahun 2003 tentang Sistem Pendidikan Nasional pada penjelasan pasal 35, di mana kompetensi lulusan merupakan kualifikasi kemampuan lulusan yang mencakup sikap, pengetahuan, dan keterampilan sesuai dengan standar nasional yang telah disepakati.

Oleh karena itu guru sebagai ujung tombak pelaksanaan pembelajaran sebagai impelemntasi kurikulum harus memiliki kompetensi terutama kompetensi paedagogik. UU RI No 14 tahun 2005 tentang Guru dan Dosen dalam Ketentuan Umum pasal 1ayat 10 dijelaskan bahwa kompetensi adalah seperangkat pengetahuan, keterampilan dan perilaku yang harus dimiliki, dihayati, dikuasai oleh guru atau dosen dalam melaksanakan tugas keprofesionalan. Sedangkan kompetensi guru dijalaskan dalam pasal 10 ayat 1 bahwa "kompetensi guru sebagaimana dimaksud dalam Pasal 8 meliputi kompetensi pedagogik, kompetensi kepribadian, kompetensi sosial, dan kompetensi profesional yang diperoleh melalui pendidikan profesi”. Berdasarkan Undang-Undang No. 14 tahun 2005 tentang Guru dan Dosen dijelaskan bahwa kompetensi pedagogik merupakan kemampuan seorang guru dalam mengelola proses pembelajaran yang berhubungan dengan peserta didik, meliputi pemahaman wawasan atau landasan kependidikan, pemahaman terhadap peserta didik, pengembangan kurikulum atau silabus, perancangan pembelajaran, pelaksanaan pembelajaran yang mendidik dan dialogis, pemanfaatan teknologi pembelajaran, evaluasi hasil belajar, dan pengembangan peserta didik untuk mengaktualisasikan berbagai potensi yang dimilikinya.

Berdasarkan regulasi di atas maka, salah satu kompetensi pedagogik adalah penyusunan rencana pelaksanaan pembelajaran (RPP). Keberhasilan guru dalam menyusun RPP pada perencanaan pembelajaran akan menentukan keberhasilan pelaksanaan pembelajaran. Oleh karena itu, RPP yang disusun guru harus sesuai dengan kurikulum 2013. Permendikbud Nomor 65 Tahun 2013 tentang standar proses, Rencana pelaksanaan pembelajaran adalah rencana kegiatan pembelajaran tatap muka untuk satu pertemuan atau lebih dan RPP dikembangkan dari silabus untuk mengarahkan kegiatan pembelajaran peserta didik dalam upaya mencapai kompetensi dasar (Daryanto, dkk. 2014: 87). Sedangkan Muhaimin (2005), perencanaan bila dikaitkan dengan istilah pembelajaran dapat diartikan sebagai proses mempersiapkan kegiatan pembelajaran secara sistematis yang akan dilakukan untuk mencapai tujuan pembelajaran yang telah ditetapkan. Kegiatan pokok yang dilakukan oleh pendidik (dalam hal ini dosen) pada tahap ini ada dua hal, yaitu menyusun silabus dan satuan acara perkuliahan (SAP) (Sukiman, 2015:165).

Tekait dengan penelitian ini perancangan pembelajaran merupakan salah satu kompetensi pedagogik yang harus dimiliki guru. Perancangan pembelajaran sedikitnya mencakup tiga kegiatan, yaitu: (a) Identifikasi kebutuhan; (b) Identifikasi kompetensi; (c) Penyusunan program pembelajaran (Mulyasa, 2007: 100). Sedangkan Abdul Majid, dalam konteks pengajaran, perencanaan dapat diartikan sebagai proses penyusunan materi pelajaran, penggunaan media pengajaran, penggunaan pendekatan dan metode pengajaran, dan penilaian dalam suatu alokasi waktu yang akan dilaksanakan pada masa tertentu untuk mencapai tujuan yang telah ditentukan (Majid, 2005: 15-17).

Menurut Hamalik, ada beberapa hal yang harus diperhatikan dalam membuat rencana pembelajaran yaitu: (a) Rencana yang dibuat harus disesuaikan dengan tersedianya sumber-sumber; (b) Organisasi pembelajaran harus senantiasa memperhatikan situasi dan kondisi masyarakat sekolah; (c) Guru selaku pengelola pembelajaran harus melaksanakan tugas dan fungsinya dengan penuh tanggung jawab (Hamalik, 2009: 50).

Permendikbud No.22 tahun 2016 menjelaskan bahwa perencanaan pembelajaran dirancang dalam bentuk Silabus dan Rencana Pelaksanaan Pembelajaran (RPP) yang mengacu pada Standar Isi. Selanjutnya dijelakan bahwa komponen-kompenen dalam RPP: identitas mata pelajaran, kompetensi inti, tujuan pembelajaran, kompetensi dasar, indikator pencapaian kompetensi, materi ajar, alokasi waktu, metode pembelajaran, kegiatan pembelajaran, sumber belajar dan penilaian. Berdasarkan uraian 
di atas maka peneliti tertarik untuk mengangkat judul penelitian: Analisis Desain Rencana Pelaksanaan Pembelajaran (RPP) pada Mata Pelajaran Sejarah di SMA Negeri 1 Sanggar.

\section{Metode}

Penelitian ini menggunakan pendekatan kualitatif dengan metode deskripstif. Penelitian penelitian deskriptif kualitatif akan menghasilkan data deskriptif berupa kata-kata. Artinya data yang dianalisis di dalamnya berbentuk deskriptif dan tidak berupa angka-angka seperti halnya pada penelitian kuantitatif (Moleong, 2008: 3).

Pengumpulan data adalah menggunakan teknik studi dokumentasi berupa Silabus dan RPP mata pelajaran sejarah di SMA Negeri 1 Sanggar. Teknik dokumentasi digunakan peneliti untuk menyelidiki benda-benda tertulis seperti buku, dokumen tugas siswa, peraturan-peraturan, dan catatan harian (Arikunto, 2002: 135). Pisau analisis yang digunakan adalah Peraturan Menteri Pendidikan dan Kebudayaan Nomor 22 Tahun 2016 tentang Standar Proses Pendidikan Dasar dan Menengah. Dokumentasi memiliki peranan penting dalam pengumpulkan data penelitian.

Validasi data menggunakan teknik meningkatkan ketekunan dengan membaca berbagai sumber terkait objek peneltian serta triangulasi teori. Triangulasi teori menurut Lincoln dan Guba dalam Moleong (2014: 331), berdasarkan anggapan bahwa fakta tidak dapat diperiksa derajat kepercayaannya dengan satu atau lebih teori. Analisis data merujuk peda pendapat Miles dan Huberman (1884) mengemukakan bahwa aktivitas dalam analisis data kualitatif dilakukan secara interaktif dan berlangsung secara terus menerus sampai tuntas, sehingga datanya sudah jenuh. Aktivitas dalam analisis data yaitu data reduction, data display, conclusion drawing/verification (Sugiono, 2013:337).

\section{Hasil dan Pembahasan}

Salah satu bentuk profesionalisme guru adalah dengan menyusun program pengajaran terlebih dahulu sebelum melaksanakan pembelajaran di kelas. Perencanaan perlu disusun agar pembelajaran yang dilakukan terencana dan tersusun dengan baik. Maka semua guru mata pelajaran diwajibkan membuat suatu program perencanaan pembelajaran, seperti kaldik, program tahunan, program semester, KKM, silabus, RPP (Rencana Pelaksanaan Pembelajaran), termasuk guru sejarah. Pisau analisis yang digunakan adalah Peraturan Menteri Pendidikan dan Kebudayaan Nomor 22 Tahun 2016 tentang Standar Proses Pendidikan Dasar dan Menengah.

\section{Analisis Kelengkapan dan Sistematika Penyusunan Komponen RPP}

Berdasarkan hasil studi dokumen terhadap rencana pelaksanaan pembelajaran (RPP) di SMA Negeri 1 Sanggar bahwa komponen-komponen dalam RPP mata pelajaran sejarah baik di kelas I, kelas II maupun kelas III dimana setiap kelas diambil masing-masing dua buah secara random sehingga jumlah RPP yang dianalisa sebanyak enam buah. Berdasarkan analisa dokumen bahwa RPP pada mata pelajaran Sejarah di SMA Negeri 1 Sanggar memiliki komponen-komponen yang terdiri dari: Identitas dan Alokasi Waktu, Kompetensi Inti (KI), Kompetensi Dasar dan Indikator, Tujuan Pembelajaran, Materi Pembelajaran, Metode Pembelajaran, Media, Sumber, Langkah-langkah kegiatan Pembelajaran Pembelajaran Remedial dan Pengayaan

Perbandingan antara komponen RPP yang bersadarkan Peraturan Menteri Pendidikan dan Kebudayaan Nomor 22 Tahun 2016 dengan komponen RPP yang dikembangkan guru SMA Negeri 1 Sanggar seperti dalam tabel 1.

Berdasarkan data pada tabel 1, bahwa komponen-komponen RPP yang ditentukan oleh Permendikbud No. 22 Tahun 2016 sebanyak 11 (sebelas) komponen sedangkan RPP yang dikembangkan guru sejarah SMA Negeri 1 Sanggar 10 (sepuluh) komponen dimana komponen alokasi waktu dicantumkan dalam identitas mata kuliah sehingga secara keseluruhan komponen-komponen dalam RPP yang dikembangkan oleh 
guru sejarah SMA Negeri 1 Sanggar sesuai dengan ketentuan Peraturan Menteri Pendidikan dan Kebudayaan Nomor 22 Tahun 2016. Perbedaannya ada pada sistematika RPP dimana dalam RPP yang dikembangkan oleh guru SMA Negeri 1 Sanggar dimana komponen “Tujuan Pembelajaran” dikembangkan setelah perumusan KD sedangkan dalam Permendikbud No. 22 Tahun 2016 dimana komponen “Tujuan Pembelajaran” sebelum KD. Dengan demikian dapat disimpulkan bahwa komponen-komponen RPP yang dikembangkan oleh guru sejarah SMA Negeri 1 Sanggar sama dengan ketentuan Permendikbud No. 22 Tahun 2016 sedangkan perbedaannya pada sistematikanya.

Tabel 1: Perbandingan komponen RPP bersadarkan Permendikbud No. 22 Tahun 2016 dengan komponen RPP yang dikembangkan guru SMA Negeri 1 Sanggar

\begin{tabular}{ll}
\hline Permendikbud No. 22 Tahun 2016 & Guru SMA Negeri 1 Sanggar \\
\hline A. Identitas mata pelajaran, & A. Identitas dan Alokasi Waktu \\
B. Kompetensi inti, & B. Kompetensi Inti (KI) \\
C. Tujuan pembelajaran, & C. Kompetensi Dasar dan Indikator \\
D. Kompetensi dasar, & D. Tujuan Pembelajaran \\
E. Indikator pencapaian kompetensi, & E. Materi Pembelajaran \\
F. Materi ajar, & F. Metode Pembelajaran \\
G. Alokasi waktu, & G. Media Pembelajaran \\
H. Metode pembelajaran, & H. Sumber belajar \\
I. Kegiatan pembelajaran, & I. Langkah-langkah Pembelajaran \\
J. Sumber belajar dan & J. Pembelajaran Remedial dan Pengayaan \\
K. Penilaian. & \\
\hline
\end{tabular}

\section{Analisis Kesesuaian Isi RPP}

Sedangkan komponen isi dari rumusan kompetensi dasar (KD) sampai Penilaian berdasarkan analisa peneliti dapat diuraikan sebagai berikut. Pada materi pokok "Perkembangan Kolonialisme dan Imperialisme Eropa" mata pelajaran sejarah kelas XI perumusan KD adalah "Menganalisis proses masuk dan perkembangan penjajahan bangsa Eropa (Portugis, Spanyol, Belanda, Inggris) ke Indonesia". Demikian halnya dengan materi pokok kelas XII pada materi pokok "Kehidupan politik dan ekonomi pada masa Reformasi" dimana KD dirumuskan adalah "Menganalisis perkembangan kehidupan politik dan ekonomi Bangsa Indonesia pada masa awal Reformasi”. Berdasarkan dua rumusa KD di atas, guru mata pelajaran sejarah senantiasa memperhatikan kemampuan yang akan diperoleh siswa setelah mempelajari materi di atas. Dalam Permendikbud No. 22 Tahun 2016 dijelaskan bahwa perumusan KD merupakan kemampuan spesifik yang mencakup sikap, pengetahuan, dan keterampilan yang terkait muatan atau mata pelajaran (Depdikbud, 2016: 5).

Permusan tujuan pembelajaran yang dilakukan oleh guru mata pelajaran sejarah SMA Negeri 1 Sanggar misalnya pada kelas X semester ganjil dengan materi pokok "Indonesia Zaman Praaksara: Awal Kehidupan Manusia Indonesia" dimana tujuan pembelajaran dirumuskan dengan kata kerja berdasarkan tingkat kemampuan yang menjadi tujuan pembelajaran. Berdasarkan materi di atas maka guru mata pelajaran sejarah merumuskan C2 yaitu "Memahami peta persebaran asal-usul nenek moyang bangsa Indonesia”. Di sini guru bertujuan agar siswa mampu memahami persebaran asal-usul nenek moyang bangsa Indonesia".

Dalam rangka mencapai tujuan pembelajaran di atas guru mata pelajaran sejarah di SMA Negeri 1 Sanggar harus menyiapkan materi sesuai dengan tujuan pembelajaran di atas. Dalam RPP kelas XI semester genap dengan materi pokok "Perjuangan Mempertahankan Kemerdekaan dari Ancaman Sekutu \& Belanda”. Indikator yang ingin dicapai dalam kompetensi dasar adalah Mendeskripsikan konflik Indonesia-Belanda dalam upaya mempertahankan kemerdekaan; Menganalisis bentuk dan strategi perjuangan menghadapi ancaman Sekutu; Menganalisis bentuk dan strategi perjuangan menghadapi ancaman Belanda. 
Permendikbud No. 22 Tahun 2016 menjelaskan bahwa materi atau materi pokok, memuat fakta, konsep, prinsip, dan prosedur yang relevan, dan ditulis dalam bentuk butir-butir sesuai dengan rumusan indikator pencapaian kompetensi (Depdikbud, 2016: 6). Maka materi pelajaran yang dirumuskan oleh guru adalah (a) Bentuk dan strategi perjuangan menghadapi ancaman Sekutu; (b) Bentuk dan strategi perjuangan menghadapi ancaman Belanda. Materi di atas akan membahas bentuk dan strategi bangsa Indonesia menghadapi kedatangan kembali Belanda yang dibonceng Sekutu yang bertujuan menjajah kembali Indonesia bangsa Indonesia menghadapinya dengan dua bentuk strategi yaitu perjuangan bersenjata dan berjuangan diplomasi. Hasil perjuangan bangsa Indonesia dimana Belanda mengakui kedaulatan bangsa Indonesia dalam perundingan Meja Bundar di Den HaagBelanda pada 23 Agustus 1949-2 November 1949. Terkait materi di atas dijelaskan pelajaran sejarah di SMA/MA adalah mata pelajaran yang mengkaji permasalahan dan perkembangan masyarakat dari masa lampau sampai masa kini, baik di Indonesia maupun di luar Indonesia (Agung dkk., 2013: 61).

Peneliti kemudian menganalisa RPP kelas XII semester ganjil dengan materi pokok "Kehidupan politik, ekonomi, sosial, dan budaya bangsa Indonesia pada masa awal kemerdekaan”. Model pembelajaran yang diterapkan adalah Discovery Learning dengan metode Tanya jawab, wawancara, diskusi dan bermain peran. Permendikbud No. 22 Tahun 2016 menjelaskan bahwa metode pembelajaran digunakan oleh pendidik untuk mewujudkan suasana belajar dan proses pembelajaran agar peserta didik mencapai KD yang disesuaikan dengan karakteristik peserta didik dan KD yang akan dicapai (Depdikbud, 2016: 7). Beberapa model pembelajaran yang disarankan antara lain Inquiry learning, Project Based Learning, Discovery Learning. Penerapan model pembelajaran ini harus sesuai dengan tujuan pembelajaran misalnya, model Project Based Learning bertujuan untuk mendorong peserta didik menghasilkan karya kreatif dan kontekstual, baik individual maupun kelompok, disarankan yang menghasilkan karya berbasis pemecahan masalah (Depdikbud, 2016: 12).

Desain perencanaan pelaksanaan pembelajaran guru mata pelajaran sejarah memanfaatkan media pembelajaran. Media merupakan alat bantu yang dapat berupa apa saja yang dapat dijadikan sebagai penyalur pesan guna mencapai tujuan pembelajaran (Djamarah, 2010:120). Berdasarkan dokumen RPP yang dikumpulkan oelh peneliti ada beberapa media yang digunakan dalam pembel;ajaran sejarah di SMA Negeri 1 Sanggar antara lain Worksheet atau lembar kerja (siswa), Lembar Penilaian, LCD Proyektor, Laptop \& infocus dan Slide presentasi (PPT) dan video pembelajaran. Permendikbud No. 22 Tahun 2016 menjelaskan bahwa, media pembelajaran berupa alat bantu proses pembelajaran untuk menyampaikan materi pelajaran. Permendikbud juga menjelaskan bahwa penyusunan RPP dengan memperhatikan prinsip penerapan teknologi informasi dan komunikasi secara terintegrasi, sistematis, dan efektif sesuai dengan situasi dan kondisi (Depdikbud, 2016: 8). Pemanfaatan media pembelajaran ini juga didukung oleh hasil penelitian Ainina dari Jurusan Sejarah, Fakultas Ilmu Sosial, Universitas Negeri Semarang yang berjudul Pemanfaatan Media Audio Visual sebagai Sumber Pembelajaran Sejarah. Penelitian tersebut menggunakan pendekatan kuantitatif dengan jenis penelitian eksperimen. Hasil penelitian bahwa terdapat pengaruh positif media pembelajaran sejarah berbasis audio visual terhadap hasil belajar sejarah siswa kelas XI SMA Negeri 2 Bae Kudus tahun ajaran 2013/2014.

Mata pelajaran sejarah harus memiliki sumber yang jelas dan relengan dengan tujuan pembelajaran. Dalam RPP kelas XI pada materi pokok "Pendidikan dan Pergerakan" sumber belajar yang digunakan adalah buku Sejarah Indonesia Siswa Kelas XI dari Kemendikbud Tahun 2016, internet dan majalah dan koran. Sumber belajar di atas sesuai dengan yang ditentukan oleh Permendikbud No. 22 Tahun 2016 yang mejelaskan bahwa sumber belajar dapat berupa buku, media cetak dan elektronik, alam sekitar, atau sumber belajar lain yang relevan (Depdikbud, 2016: 7).

Komponen langkah-langka pembelajaran dalam RPP yang dikembangkan oleh guru mata pelajaran sejarah SMA Negeri 1 Sanggar sebagai berikut: (a) Kegiatan Pendahuluan dengan alokasi 
waktu 15 menit, (b) Kegiatan Inti dengan alokasi waktu 60 Menit dan, (c) Kegiatan Penutup dengan alokasi waktu sebanyak 15 menit. Pelaksanaan pembelajaran merupakan implementasi dari RPP, meliputi kegiatan pendahuluan, inti dan penutup (Depdikbud, 2016: 11). Berdasarkan keterangan di atas bahwa ada kesesuaian antara desain RPP yang dikembangkan oleh guru mata pelajaran sejarah SMA Negeri 1 Sanggar dengan ketentuan dari Permendikbud No. 22 Tahun 2016.

Komponen terakhir yang dianalisis adalah penilaian dimana dalam RPP yang dikembangkan oleh guru sejarah SMA Negeri 1 Sanggar terdiri dari penilaian ranah afeksi (sikap) menggunakan instrumen observasi. Penilaian sikap siswa juga mengembangkan penilaian diri dan penilaian teman sebaya. Ranah kognitif (pengetahuan) menggunakan teknik tertulis dengan instrumen soal uraian dan pilihan ganda sedangkan ranah psikomotoris (keterampilan) menggunakan instrumen observasi dalam penilaian Unjuk Kerja. Misalnya untuk menilai siswa dalam berdiskusi, guru mengembangkan instrumen observasi sebagai berikut:

\begin{tabular}{clcccc}
\hline No & \multicolumn{1}{c}{ Aspek yang Dinilai } & 100 & 75 & 50 & 25 \\
\hline 1 & Penguasaan materi diskusi & & & & \\
2 & Kemampuan menjawab pertanyaan & & & & \\
3 & Kemampuan mengolah kata & & & & \\
4 & Kemampuan menyelesaikan masalah & & & \\
\hline
\end{tabular}

\section{Keterangan:}

100 = Sangat Baik

$75=$ Baik

50 = Kurang Baik

$25=$ Tidak Baik

Kegiatan remedial bagi siswa yang belum mencapai KKM, guru menyusun beberapa soal tes uraian sedangkan kegiatan pengayaan dimana guru memberikan nasehat misalnya siswa diminta membaca beberapa sumber yang relevan, membaca surat kabar dan mencari informasi online. Penilaian proses pembelajaran menggunakan pendekatan penilaian otentik (authentic assesment) yang menilai kesiapan peserta didik, proses, dan hasil belajar secara utuh. Hasil penilaian otentik digunakan guru untuk merencanakan program perbaikan (remedial) pembelajaran, pengayaan (enrichment), atau pelayanan konseling. Selain itu, hasil penilaian otentik digunakan sebagai bahan untuk memperbaiki proses pembelajaran sesuai dengan Standar Penilaian Pendidikan.

Evaluasi proses pembelajaran dilakukan saat proses pembelajaran dengan menggunakan alat: lembar pengamatan, angket sebaya, rekaman, catatan anekdot, dan refleksi. Evaluasi hasil pembelajaran dilakukan saat proses pembelajaran dan di akhir satuan pelajaran dengan menggunakan metode dan alat: tes lisan/perbuatan, dan tes tulis. Hasil evaluasi akhir diperoleh dari gabungan evaluasi proses dan evaluasi hasil pembelajaran (Depdikbud, 2016: 13).

\section{Kesimpulan}

Berdasarkan uraian-uraian di atas dapat disimpulkan sebagai berikut: (a) Desain rencana pelaksanaan pembelajaran (RPP) yang dikembangkan oleh guru mata pelajaran sejarah di SMA Negeri 1 Sanggar sesuai dengan ketentuan dari Permendikbud No. 22 Tahun 2016. Perbedaannya ada pada sistematika dimana RPP Desain rencana pelaksanaan pembelajaran (RPP) yang dikembangkan oleh guru mata pelajaran sejarah di SMA Negeri 1 Sanggar merumuskan tujuan pembelajaran setelah KD dan Indokator sedangkan Permendikbud No. 22 Tahun 2016 merumuskan KD dan indikator setelah tujuan pembelajaran. (b) Isi Desain rencana pelaksanaan pembelajaran (RPP) yang dikembangkan oleh guru mata pelajaran sejarah di SMA Negeri 1 Sanggar sesuai dengan ketentuan Permendikbud No. 22 Tahun 2016. 


\section{Daftar Pustaka}

Agung, Leo \& Sri Wahyuni, (2013). Perencanaan Pembelajaran Sejarah. Yogyakarta: Ombak.

Alhamuddin. (2014). Sejarah Kurikulum di Indonesia (Studi Analisis Kebijakan Pengembangan Kurikulum). Jurnal Nur El-Islam, Volume 1, Nomor 2, Oktober 2014, Bandung: Universitas Pendidikan Indonesia (UPI).

Arikunto, Suharsimi. (2002). Dasar-Dasar Evaluasi Pendidikan, Jakarta: Bumi Aksara.

BSNP. (2016). Salinan lampiran peraturan Kementrian Pendidikan dan kebudayaan Republik Indonesia No.22 tahun 2016 tentang Standar Proses Pendidikan Dasar dan Menengah.

Daryanto, dkk. (2014). Pengembangan Perangkat Pembelajaran (Silabus, RPP, PHB, dan Bahan Ajar). Yogyakarta: Penerbit Gaya Media.

Depdiknas. (2003). Undang-undang Republik Indonesia Nomor 20 Tahun 2003 tentang Sistem Pendidikan Nasional.

Depdiknas. (2005. Undang-undang Republik Indonesia No 14 tahun 2005 tentang Guru dan Dosen.

Hamalik, Oemar. (2009). Perencanaan Pengajaran Berdasarkan Pendekatan Sistem, Jakarta: PT Bumi Aksara.

Kemendikbud. (2016). Peraturan Menteri Pendidikan dan Kebudayaan Nomor 22 Tahun 2016 tentang Standar Proses Pendidikan Dasar dan Menengah, Jakarta.

Kemendikbud. (2013). Peraturan Menteri Pendidikan dan Kebudayaan Republik Indonesia Nomor 81A Tahun 2013 Tentang Implementasi Kurikulum, Jakarta.

Kochhar, S.K. (2008). Pembelajaran Sejarah, Jakarta: Grasindo.

Majid, Abdul. (2005). Perencanaan Pembelajaran. Bandung: PT Remaja Rosdakarya.

McNeil \& John D. (2006). Contemporary Curriculum. New York: John Willey \& Son.

Moleong, Lexy J. (2104). Metodologi Penelitian Kualitatif (edisi revisi), cet. 32, PT Remaja Rosdakarya. Bandung.

Mulyasa, E. (2007). Standar Kompetensi dan Sertifikasi Guru. Bandung: Remaja Rosdakarya.

Peraturan Pemerintah. (2005). Peraturan Pemerintah Republik Indonesia No.19 Tahun 2005 pasal 20 tentang Standar Proses. Jakarta.

Poerwati, Loeloek Endah dan Sofan Amri. (2013). Panduan Memahami Kurikulum 2013. Jakarta: PT. Prestasi Pustakarya.

Rowse, A.L. (2014). Apa Guna Sejarah? Depok: Komunitas Bambu.

Rusman. (2009). Manajemen kurikulum. Jakarta: Rajawali Pers.

Sugiono. (2013). Metode Penelitian Pendidikan, Pendekatan Kuantitatif, Kualitatif dan R EF D. cet. ke-18, Bandung: Alfabet.

Sukiman. (2015). Pengembangan Kurikulum di Perguruan Tinggi. Bandung: Remaja Rosdakarya. 